\title{
Study of Morphology of Placenta in Fifty Specimens
}

\section{Dhinesh Kumar ${ }^{1}$, Muthuprasad *2.}

${ }^{1}$ Assistant professor, Anatomy department, Dhanalakshmi sreenivasan Medical College, Perambalur, Tamilnadu, India.

*2 Associate professor, Anatomy department, KAPV government medical college, Trichy Tamilnadu, India.

\section{ABSTRACT}

Introduction: The placenta is an important organ for keeping a pregnancy going and promoting normal foetal development. As a foetal organ, the placenta is subjected to the same stress and strain as the foetus. The growth of the foetus depends upon the

location, functional capacity and integrity of the placental attachment.

Aim: To study the morphology of the placenta in fifty placental specimens.

Methods: The study was conducted in the Institute of Anatomy, Madurai Medical College, in collaboration with the Department of Obstetrics and Gynecology. A total of fifty placental specimens were collected and analyzed for shape, diameter, thickness, placenta weight, maternal and fetal cotyledons, and attachment of cord, vascular pattern, fetoplacental ratio and placental co-efficient.

Results: In fifty placentae, $60 \%$ circular in shape; $38 \%$ oval in shape; $2 \%$ triangular in shape. The mean diameter is $17.7 \mathrm{~cm}$. The diameter is increased in anaemia and decreased in prematurity. The average thickness is 1.993 $\mathrm{cm}$. The thickness is increased in Diabetes mellitus and decreased in anaemia. The average number of maternal cotyledons is 17; increased in Diatebes mellitus and decreased in prematurity. The average number of fetal cotyledons is 59 and increased in Diabetes mellitus. The feto-maternal cotyledon ratio is 3.5:1. It is increased in prematurity and decreased in Diabetes mellitus. The average weight of the placenta is 471 grams. The placental weight is increased in Diabetes mellitus and decreased in prematurity. The fetoplacental weight ratio is 5.805 and is decreased in prematurity. The placental coefficient is 0.18 and is increased in prematurity.

Conclusion: The examination of the placenta yields valuable information regarding the intra-uterine events and fetal outcome.

KEY WORDS: Placenta, Macroscopic Morphology, Pregnancy

Corresponding Author: Dr. Muthuprasad, Associate professor, Anatomy department, KAPV government medical college, Trichy Tamilnadu, India. E-Mail: jabarali2009@gmail.com

Access this Article online

Quick Response code

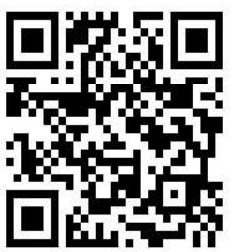

DOI: $10.16965 /$ ijar.2021.131

\begin{tabular}{|c|c|c|}
\hline \multicolumn{3}{|c|}{ Journal Information } \\
\hline \multicolumn{3}{|c|}{$\begin{array}{l}\text { International Journal of Anatomy and Research } \\
\text { ISSN (E) 2321-4287 | ISSN (P) 2321-8967 } \\
\text { https://www.ijmhr.org/ijar.htm } \\
\text { DOI-Prefix: https://dx.doi.org/10.16965/ijar }\end{array}$} \\
\hline \multicolumn{3}{|c|}{ Article Information } \\
\hline $\begin{array}{l}\text { Received: } 15 \text { Apr } 2021 \\
\text { Peer Review: } 16 \text { Apr } 2021 \\
\text { Revised: None }\end{array}$ & $\begin{array}{l}\text { Accepted: } 10 \text { May } \\
\text { Published (O): } 05 \\
\text { Published (P): } 05\end{array}$ & $\begin{array}{l}21 \\
2021 \\
2021\end{array}$ \\
\hline
\end{tabular}

\section{INTRODUCTION}

Placenta has characteristic of eutherian or placental mammals. The word placenta comes from the Latin for cake, from greek "Plakoenta / plakounta, accusative of plakoeis/ plakous, flat, slab -like about its round, flat appearance in humans. The human placenta is a villous haemochorial structure of critical importance in maternal - fetal transfer. It has a complex synthetic capacity and plays a fundamental role in the fetal allograft's immunological acceptance [1]. The placental complex formed by the combined effort between the extra The embryonic tissue of the embryo and the 
mother's endometrial tissue represent symbiosis between the two separate beings without rejection. The formation of the placenta is a biological event that is important both embryological and immunologically [2]. The placenta serves the most basic fetus's most basic metabolic needs, including respiration, nourishment, and excretion, by acting as temporary lung, liver and kidney. It forms an organ for the interchange of material between fetal and maternal bloodstreams without mixing or physical contact with two bloodstreams. The placenta carries out important tasks like hormone synthesis, protein synthesis, immunological role, and endocrine secretion production [3]. The placenta subserves these purposes until sufficient maturation of the fetus, enabling it to survive in the extrauterine environment. The growth of the fetus depends upon the functional capacity, location and integrity of the placental attachment. ${ }^{4}$ The placenta is analogous to organs like liver, lung, and kidney function but not homologues with them in structure.

The examination of the placenta soon after the delivery is vital as it gives mirror images of fetal development. It forms the morphological record of anatomical condition, intrauterine events and intrapartum events of gestation. In the case of fetal death, the examination of the placenta is mandatory, and examination of the placenta yields valuable information for the management of mother and foetus $[4,5]$. The handy information regarding the placenta is useful for obstetricians, which protects them from medico legal problems in maternal and fetal events. Ultrasonographic examination of the placenta is an important part of the obstetrical evaluation of pregnancy. The advent of ultrasonography antenatal evolution of the placenta has become essential in all pregnant patients as fetal problems and neonatal outcome depend upon the placenta's growth and abnormalities [6].

AIM: To study the morphological features of the placenta in fifty specimens.

\section{MATERIALS AND METHODS}

The present study was conducted in thelnstitute of Anatomy, Madurai Medical College, Madurai, in collaboration with the Department of Obstetrics and Gynecology of Government Rajaji Hospital, Madurai. A total of fifty freshly delivered placentae with umbilical cord were collected from the Department of Obstetrics and Gynecology, Government Rajaji Hospital, Madurai. The specimens were collected soon after their expulsion from normal deliveries and caesarean section.

The placentae and umbilical cord were collected from the following:

1. Uncomplicated primigravida and multigravida cases contributed to 44 specimens, of which male and female conceptus placentae were 26 and 18, respectively.

2.Pathological conditions and factors complicating pregnancies contributing to 6 specimens, of which 1 are male conceptus and 5 are female conceptus.

The collected specimens were washed in tap water; membranes were examined and then trimmed. The specimens were then transported to the Institute of Anatomy, Madurai Medical College, Madurai, in 10\% formalin filled plastic container.

The following parameters were studied in the specimens and are tokened from 1 to 50 numbers. The observations were photographed and variations noted.

Initially, the vernier calliper was checked for zero error with jaws closed. The calliper's jaws were placed on either side of the peripheral margin of the placenta with firm pressure on the placental surface. When both the locking screws of the calliper were tightened, the calliper was removed from the placenta. The readings were recorded after the measurement in the calliper's digital screen was corrected to the nearest tenth of the centimetre.

Maternal Surface: The number of cotyledons was counted and recorded.

Placental Weight: The weight of the placenta was recorded using a weighing scale. Babies (conceptus) whose placenta was also examined for the following facts:-

- Sex of the baby was recorded. 
- Weight of the baby recorded by a weighing scale.

- Maturity of the baby was noted.

Preterm conceptus was babies born before 37 weeks of gestation. Term conceptus was babies born from 38-40 weeks of gestation.

Fetal Surface: Type of insertion of the umbilical cord was noted. By dissection method, the number of fetal cotyledons was dissected out and counted.

Feto - Placental Ratio: It is calculated by the ratio of fetal weight by placental weight.

Placental Coefficient: It is calculated by the ratio of placental weight by fetal weight.

\section{RESULTS}

Of the fifty placental specimens, forty-four were collected from uncomplicated pregnancies and six specimens from complicated pregnancies. (Table 1) Out of the 50 placentae, 30 placentae were circular $(60 \%)$, 19 placentae were oval (38\%) and one placenta was triangular (2\%). (table 2) Out of the fifty placentae, the diameter varied from $14.60-20.90 \mathrm{cms}$. The maximum diameter is $20.90 \mathrm{cms}$ and the minimum diameter is 14.60 cms. (table 3) Out of the 50 placentae, the thickness varied from $1.612 \mathrm{cms}-2.516 \mathrm{cms}$. The minimum thickness is $1.612 \mathrm{cms}$ and the maximum thickness is $2.516 \mathrm{cms}$. (Table 4) Out of the 50 placentae, the thickness varied from $1.612 \mathrm{cms}-2.516 \mathrm{cms}$. The minimum thickness is $1.612 \mathrm{cms}$ and the maximum thickness is $2.516 \mathrm{cms}$. (table 5) The fetoplacental ratio observed in 50 cases ranged between $4.3-7.6$ and the placental co-efficient varied between $0.14-0.23$. Out of the fifty placental specimens, the number of maternal cotyledons ranged

between 12 to 20 and fetal cotyledons ranged from 36 to 84 . The ratio of maternal to fetal cotyledon ranged between 2.6 to 4.6. Out of the fifty placental specimens, Central attachment was observed in $26 \%$ of cases, Eccentric attachment in 54\%, Marginal attachment in $18 \%$ and Velamentous attachment in $02 \%$ of cases. (Table 6) Out of the 50 placental specimens, Disperse type of vascular pattern was observed in $64 \%$, the Magistral type was observed in $14 \%$ and the Mixed type was observed in $22 \%$ of cases. (Table 7 )

Table 1: Type of pregnancy.

\begin{tabular}{ccc}
\hline Specimen & $\begin{array}{c}\text { No. of Male } \\
\text { Conceptus } \\
\text { placentae }\end{array}$ & $\begin{array}{c}\text { No. of female } \\
\text { conceptus } \\
\text { placentae }\end{array}$ \\
\hline $\begin{array}{c}\text { 44 uncomplicated } \\
\text { pregnancy }\end{array}$ & 26 & 18 \\
\hline complicated pregnancy & 1 & 5 \\
\hline Total & 27 & 23 \\
\hline
\end{tabular}

Table 2: Shape of the placenta.

\begin{tabular}{ccc}
\hline $\begin{array}{c}\text { The shape of the } \\
\text { placentae }\end{array}$ & $\begin{array}{c}\text { Number of } \\
\text { placentae }\end{array}$ & $\begin{array}{c}\text { Percentage } \\
\text { (\%) }\end{array}$ \\
\hline Circular & 30 & $60.00 \%$ \\
Oval & 19 & $38.00 \%$ \\
Triangular & 1 & $2.00 \%$ \\
\hline
\end{tabular}

Table 3: Diameter of the placentae.

\begin{tabular}{ccc}
\hline $\begin{array}{c}\text { Diameter of the } \\
\text { placenta(in cms) }\end{array}$ & $\begin{array}{c}\text { Number of } \\
\text { placenta }\end{array}$ & Percentage (\%) \\
\hline$<15$ & 1 & $2.00 \%$ \\
\hline $\mathbf{1 5 . 1 - 1 7}$ & 15 & $30.00 \%$ \\
\hline $\mathbf{1 7 . 1 - 1 9}$ & 24 & $48.00 \%$ \\
$>19$ & 10 & $20.00 \%$ \\
\hline
\end{tabular}

Table 4: Thickness of the placentae.

\begin{tabular}{ccc}
\hline $\begin{array}{c}\text { The thickness of the } \\
\text { placentae (in cms) }\end{array}$ & $\begin{array}{c}\text { Number of } \\
\text { placentae }\end{array}$ & Percentage (\%) \\
\hline$<1.75$ & 8 & $16.00 \%$ \\
$1.76-2$ & 17 & $34.00 \%$ \\
$2.1-2.25$ & 22 & $44.00 \%$ \\
$>2.26$ & 3 & $6.00 \%$ \\
\hline
\end{tabular}

Table 5: Weight of the placentae.

\begin{tabular}{ccc}
\hline $\begin{array}{c}\text { Weight of the placentae } \\
\text { (in grams) }\end{array}$ & $\begin{array}{c}\text { Number of } \\
\text { placentae }\end{array}$ & Percentage (\%) \\
\hline$<450$ & 18 & $36.00 \%$ \\
\hline $450-475$ & 11 & $22.00 \%$ \\
\hline $476-500$ & 12 & $24.00 \%$ \\
\hline $501-525$ & 7 & $14.00 \%$ \\
$>526$ & 2 & $4.00 \%$ \\
\hline
\end{tabular}

Table 6: Attachment of Cord.

\begin{tabular}{ccc}
\hline Type of attachment & $\begin{array}{c}\text { Number of } \\
\text { placentae }\end{array}$ & Percentage \\
\hline Central & 13 & $26.00 \%$ \\
\hline Eccentric & 27 & $54.00 \%$ \\
\hline Marginal & 9 & $18.00 \%$ \\
Velamentous & 1 & $2.00 \%$ \\
\hline
\end{tabular}

Table 7: Vascular Pattern of Placenta.

\begin{tabular}{ccc}
\hline Vascular pattern & $\begin{array}{c}\text { Number of } \\
\text { placentae }\end{array}$ & Percentage \\
\hline Disperse & 32 & $64.00 \%$ \\
Magistral & 7 & $14.00 \%$ \\
\hline Mixed & 11 & $22.00 \%$ \\
\hline
\end{tabular}




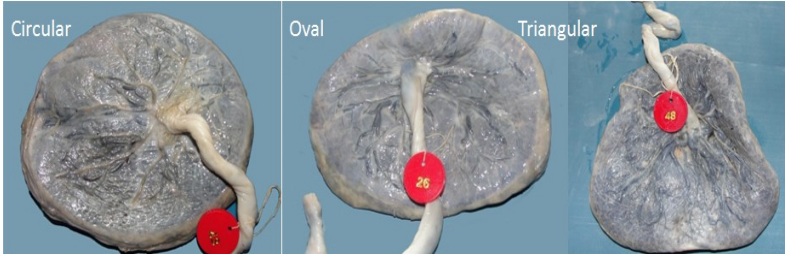

Fig. 1: Shape of placenta

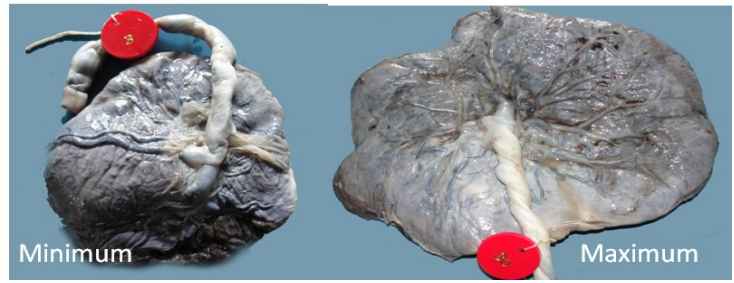

Fig. 2: Diameter of the placentae.

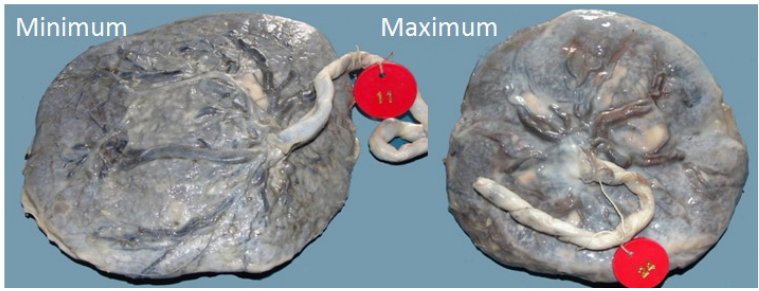

Fig. 3: Thickness of placentae.

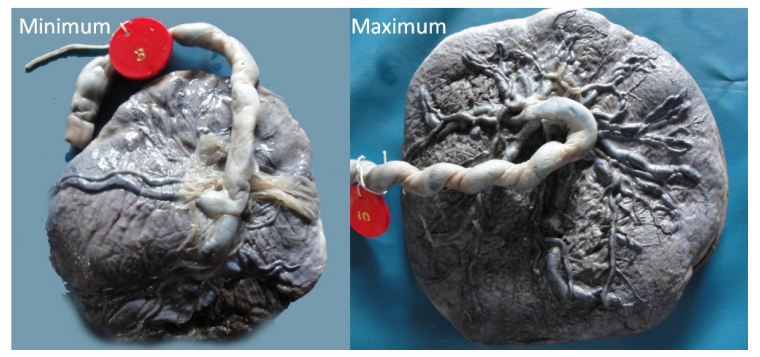

Fig. 4: Weight of the placentae.

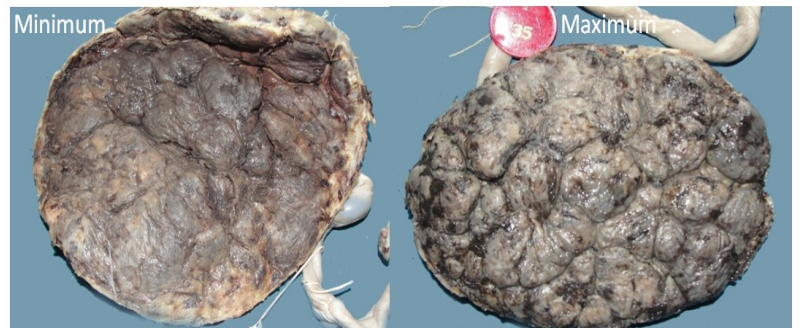

Fig. 5: Maternal cotyledons.

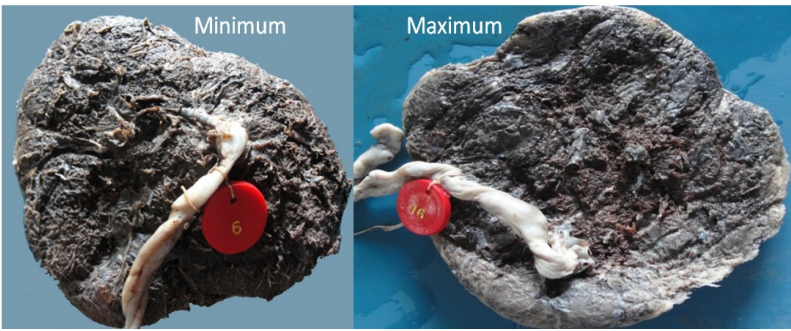

Fig. 6: Fetal cotyledons.

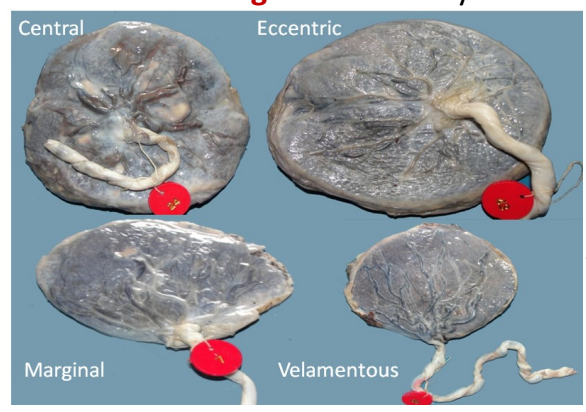

Fig. 7:

Attachment of cord.

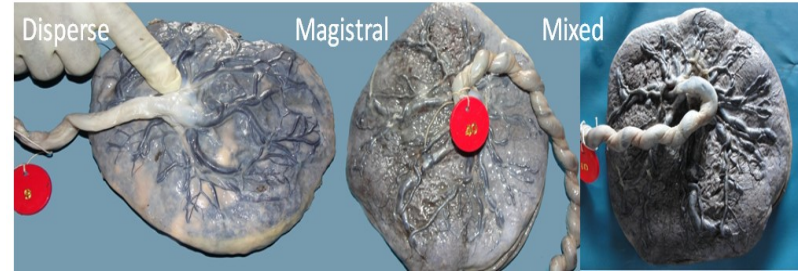

Fig. 8: Vascular pattern of placenta.

\section{DISCUSSION}

In the present study of 50 specimens, 30 circular shape placentae were observed. Out of the 30 circular shape placentae, 27 circular shape placentae was found in uncomplicated pregnancies (17 male, 10 female) and 3 circular shape placentae were observed in complicating pregnancy. The percentage of the circular placenta was $60 \%$. The incidence of percentage is similar to Sarojamma (1986) [7] and varies from Gunapriya R. (2001) [8].

In the present study, 19 oval shape placentae were noted, of which 16 oval shape placentae were observed in uncomplicated pregnancies ( 8 male, 8 female) and 3 from complicated pregnancies. The percentage of the oval placenta was $36 \%$. This finding coincides with Sarojamma (1986) [7] and greater than Gunapriya. R (2001) [8].

1 triangular placenta was observed in this study which is from uncomplicated pregnancies. The percentage of the triangular placenta in the present study was $02 \%$. This value is less than that of Sarojamma (1986) [7].

The least diameter was observed in preterm delivered placenta $(14.60 \mathrm{~cm})$ and the maximum diameter was noted in anaemia complicating pregnancy $(20.90 \mathrm{~cm})$. In the present study, the average diameter is more than Leslie. B (1924) [8]. The average diameter of the complicated pregnancies is more than the normal pregnancies.

In 44 uncomplicated pregnancies, the average thickness is $1.98 \mathrm{~cm}$. In male conceptus, the average thickness is $2.015 \mathrm{~cm}$ and in female conceptus, it is $1.947 \mathrm{~cm}$. In 6 complicated pregnancies, the average thickness is $2.0 \mathrm{~cm}$. In males, it is $2.070 \mathrm{~cm}$ and in the female, it is $2.0 \mathrm{~cm}$. This finding is similar to K.Benirschke et al. (1967) [10], and Gunapriya.R.(2001) [8]. The thickness of the placenta is increased in diabetes mellitus and reduced in anaemia and prematurity. 
In 44 uncomplicated pregnancies, the average cotyledon number is 17 . In the male conceptus placenta, it is 17 and in the female conceptus, it is 16 . In 6 complicated pregnancies, the average cotyledon number is 16 . In male conceptus, the cotyledon number is about 20 and in female conceptus, about 16 . This finding is less than Majumdar et al (2005) [9-11]. The cotyledon number is reduced in factors complicating pregnancy such as prematurity.

In 44 uncomplicated pregnancies, the average cotyledon number observed is 59 and in the male it is 59 and in the female, it is $57 . \ln 6$ complicated cases, the average number of cotyledon observed is 60 . In the male, it is 60 and in the female, it is 60 . The average number of fetal cotyledons is increased in complicated pregnancies. The above findings are less than Gray's edited by Driscoll P (2006) [12].

In 44 uncomplicated cases, the fetoplacental cotyledon ratio is 3.5 . In male conceptus, it is 3.5 and female conceptus it is 3.4 . In 6 complicated cases, the fetoplacental cotyledon ratio is 3.6. In male conceptus, it is 3.0 and female conceptus it is 3.7. The fetoplacental ratio is increased in complicated cases as in diabetes mellitus.

In the present study of 50 placentas, 32 (64\%) cases showed disperse pattern. This finding coincides with Kishore.N.Sarkar(1967) [13].

In this study of 50 placentae, central type of cord insertion was observed in 13 specimens (26\%). This value coincides with Earn.A.A (1951) [14] and more that of Shanklin D.R (1958) [15].

Eccentric type of cord insertion was observed in 27 specimens (54\%). This finding is more than that of Earn. A. A (1951) [14].

Marginal type of cord insertion was observed in 9 specimens (18\%). The above finding is more than that of Eastman N.J and HellmannL.M (1966) [16].

Velamentous type of cord insertion was observed in 1 specimen (2\%). This finding is almost similar to Uyanwah et al. (1977) [17]. The average weight of the male and female conceptus in the present study is $489.8 \mathrm{grams}$ and 448.91 grams. This finding is similar to the finding of GoshL.V and Chandrasekhar. C( 1948)
[18] and less than that of S.P.Gupta(1972) [19]. The placental weight in 44 uncomplicated pregnancies is $1 / 5.8$ of the weight of the fetus. In male conceptus, it is $1 / 5.724$ and in the female it is $1 / 5.842$. In 6 complicated cases, the observation is $1 / 5.1$. In the male, it is $1 / 5.9$ and in the female, it is $1 / 4.94$. This finding is less than that of Adair. F.L and Thealander. $\mathrm{H}$ (1946) [20] and Keith L Moore and T.V.N.Persaud (1973) [21].

\section{CONCLUSION}

The morphology of the placenta varies with the clinical conditions associated with the pregnancies. The examination of the placenta yields valuable information regarding the intra-uterine events and fetal outcome. Thus the above study will be useful for the clinicians and anatomists who are doing further research in this field.

\section{Conflicts of Interests: None}

\section{REFERENCES}

[1]. Batnagar S.M,Kotari M.L, Lopa A. Mahata. Essential of Human Embryology .3nd edition, Orient Longman, Hyderabad,2000;47-52.

[2]. Roberts RM, Green JA, Schulz LC. The evolution of the placenta. Reproduction. 2016 Nov; 152(5):R179-89.

[3]. Keith L Moore and Persaud T.V.N. Placenta and membranes.In:The Developing Human- Clinically oriented Embryology. 7th ed,Saunders, Philadelphia,2005;120-131.

[4]. Crawford. Vascular Anatomy of Human Placenta. Am.J.Obstet.Gynec, 1962;84:1543-1567

[5]. Panuganti PK, Boddeti RK. Morphology and morphometric anatomy of placenta. Int J Biol Med Res. 2012;3(3):2165-8.

[6]. Fadl S, Moshiri M, Fligner CL, Katz DS, Dighe $M$. Placental imaging: normal appearance with review of pathologic findings. Radiographics. 2017 May;37(3):979-98.

[7]. Sarojamma. Morphology and Histology study of Placenta. 1986;75-78.

[8]. Gunapriya R. The morphology, morphometric study of placenta and umbilical cord with vascular pattern and clinical correlation. 2001;28-43.

[9]. Leslie B Arey. Developmental Anatomy,7th ed, WB.Saunders, Philadelphia1974;138.

[10]. Benirschke K, Driscoll SG. The pathology of the human placenta. InPlacenta 1967 (pp. 97-571). Springer, Berlin, Heidelberg.

[11].Majumdar S, Dasgupta $H$, Bhattacharya $K$, Bhattacharya A. A study of placenta in normal and hypertensive pregnancies. J Anat Soc India. 2005;54(2):1-9. 
[12]. Driscoll P. Gray's Anatomy, 39th Edition. Emerg Med J. 2006 Jun;23(6):492.

[13]. Kishore. N and Sarkar .S.C: The arterial pattern of placenta. A post-partum radiological study. J. Obs. Gynaecol. India 17: 9 - 13 (1967)

[14]. Earn.A.A: The effect of congenital abnormalities of the umbilical cord and placenta on the new born and mother: A survey on 5676 consecutive deliveries. J. Obs.Gynaecol.Brit Emp.58:456-459.

[15]. Shanklin D.R. The Human Placenta: a clinicopathological study. J obst Gynec,1958;13:325-336.

[16]. Eastman N.J and Hellmann L.M: Williams Obstetrics ed 13, Newyork, 1966, Appleton CenteryCrofts, Inc.

[17]. Uyanwah, Akpono P.O and Fox .H ; The clinical significance of marginal or velamentous insertion of cord . Brit.J. Obstet Gynaecol, 1977;84:941-943.
[18]. Gosh. L.Vand Chandrasekhar C. A Study of the standards of prematurity of Indian infants; Govt of India Press, New Delhi 1948.

[19]. Gupta S.P, Bahl L, Dikshit S.K. A study of Placenta in relation to birth weight and gestational age . Indian J Paediatrics,1972;39(9):281-285.

[20]. Adair FL, Thelander H. A study of the weight and dimensions of the human placenta in its relation to the weight of the newborn infant. Am J Obstet Gynecol. 1925;10:172-205.

[21]. Moore KL, Persaud TV. The Developing Human: Clinically Oriented Embryology [slides]. Saunders; 1993.

How to cite this article:

Dhinesh Kumar, Muthuprasad. Study of Morphology of Placenta in Fifty Specimens.Int J Anat Res 2021;9(2.3):8020-8025. DOI: 10.16965/ ijar.2021.131 